\title{
AL-QUR'AN DAN PSIKOTERAPI ELABORASI DEDUKTIF DAN TELAAH BANDING PENDEKATAN TAFSIR INTEGRATIF DALAM TERAPI MEMAAFKAN DAN MEMINTA MAAF
}

\author{
Rohimin \\ Guru Besar IImu-IImu Alquran dan Tafsir IAIN Bengkulu \\ Email : rohimin@iainbengkulu.ac.id
}

\begin{abstract}
This paper aims to elaborate on the deductions and narratives of the al-Quran regarding psychological therapy through the therapy of forgiveness and apologizing as a Sufic spiritual teraphis. The basic assumptions that are built and developed in this paper are that forgiveness and apologizing can be used as Psychoteraphy. Deductively the al-Quran declares itself and tells humans that he is present as a healer, especially in diseases which are in the heart or mental illness. Because the al-Quran is present as learning, healing, guidance, and mercy. Besides having a calming and soul-shaking effect, the al-Qur'an also has preventive, curative, and therapeutic effects on various psychiatric, spiritual and physical ailments. The deduction and narrative of the al-Quran concerning forgiveness as contained in the al-Quran confirms that both attitudes provide solutions in the relations of life between people. Psychoteraphy forgives and apologizes is part of physical psychotherapy, a psychotherapy effort that combines Sufism and Psychotherapy approaches. The psychological element of the al-Quran as part of the building of Islamic psychology with the object of matrices of human behavior contributes to the psychiatric psychology of man.
\end{abstract}

Keywords: Al-Quran, psychotherapy, Sorry Therapy, and apologize

Abstrak: Tulisan ini bertujuan mengelaborasi deduksi dan narasi al-Quran tentang terapi psikologis melalui terapi memaafkan dan meminta maaf sebagai trapi spritual sufistik. Asumsi dasar yang dibangun dan dikembangkan dalam tulisan ini bahwa sikap memaafkan dan meminta maaf dapat dijadikan sebagai terafi kejiwaan. Secara deduktif al-Quran menyatakan dirinya dan memberi tahu kepada manusia bahwa dia hadir sebagai penyembuh, terutama terhadap penyakit-penyakit yang berada di dalam hati atau penyakit mental. Karena al-Quran hadir sebagai pembelajaran, penyembuh, petunjuk, dan rahmat. Selain memiliki efek menenangkan dan menggetarkan jiwa, al-Qur'an juga memiliki efek preventif, kuratif, dan terapeutik terhadap berbagai penyakit kejiwaan, spiritual hingga fisik. Deduksi dan narasi al-Quran tentang maaf yang termaktub di dalam al-Quran menegaskan bahwa kedua sikap tersebut memberi solusi dalam relasi kehidupan antar sesama. Psikoterafi memaaf dan meminta maaf merupakan bagian dari psikoterapi tasauf, sebuah upaya psikoterapi yang menggabungkan pendekatan tasawuf dan Psikoterapi. Elemen psikologi dari al-Quran sebagai bagian dari bangunan psikologi Islam dengan obyek matrialnya tingkah laku manusia memberi kontribusi psikoterpis kejiwaan manusia.

Kata kunci : Al-Quran, psikoterapi, Terapi Maaf, dan meminta maaf 
2 (3)

NUANSA Vol. XII, No. 1, Juni 2019

\section{Pendahuluan}

Sebagai makhluk yang memiliki kesadaran, manusia menyadari adanya problem yang mengganggu kejiwaannya, oleh karena itu sejarah manusia juga mencatat adanya upaya mengatasi problem tersebut. Upaya-upaya tersebut ada yang bersifat mistik yang irasional, ada juga yang bersifat rasional, dan ada pula yang bersifat konsepsional ilmiah. ${ }^{1}$ Secara alamiah manusia merindukan kehidupan yang tenang dan sehat, baik jasmani maupun rohani, kesehatan yang bukan hanya menyangkut badan, tetapi juga kesehatan mental. Suatu kenyataan menunjukkan bahwa peradaban manusia yang semakin maju berakibat pada semakin kompleknya gaya hidup manusia. Bersamaan dengan pesatnya modernisasi kehidupan, manusia harus menghadapi persaingan yang sangat ketat, pertarungan yang sangat tajam, satu keadaan yang menimbulkan kegalauan dan kegelisahan. ${ }^{2}$

Di antara sekian banyak problem yang mengganggu kejiwaan manusia di tengah kompleksitas pesatnya modernisasi kehidupan adalah persoalan persinggungan dan gesekan komunikasi antar sesama dan rasa bersalah pada diri sendiri terhadap orang lain. Persaingan dan pertarungan kehidupan ini pada gilirannya mengganggu ketenangan dan kebahagiaan hidup seseorang, bahkan dapat memicu gangguan kejiwaan, karena rasa bersalah terus bersemayam di dalam dirinya. Maka atas dasar kenyataan ini maaf dan meminta maaf bisa dijadikan sebagai psikoterapi spritual sufistik. Maaf dan meminta maaf dalam deduksi dan narasi al-Quran memiliki kekuatan "ajaib" dan kekuatan spritual. Kekuatan maaf memiliki dampak dalam kehidupan seseorang, sekalipun dampak kekuatannya dan intensitas memberi maaf tersebut berbeda beda, itulah sebabnya al-Quran dalam banyak ayat mengungkap persoalan maaf dalam berbagai kaitannya. ${ }^{3}$

Kitab Suci AL-Quran disamping memiliki sisi teologis eksoteris sebagai kalam maknawi dia juga memiliki sisi historis dan keilmuan yang bersifat esoteris sebagai kalam lafzhi. Dalam posisi ini maka Kitab Suci al-Quran merupakan wawasan, teori, sistem, metode, tekhnik dan pendekatan. Selain sebagai pedoman hidup, alQuran juga merupakan kitab suci umat Muslim yang dapat mendatangkan kesembuhan bagi berbagai macam penyakit melalu berbagai terapi. Upaya-upaya ini dipandang sebagai ikhtiar Penyembuhan terapis melalui media Kitab Suci (al-Quran).

Di era informasi dan globalisasi ini ada kecenderungan kebanyakan manusia lebih memperhatikan kesehatan fisik dibandingkan dengan kesehatan jiwa. Padahal sebenarnya gangguan mental emosional bisa saja disebabkan oleh masalah lingkungan, masyarakat atau pribadinya sendiri. Kondisi lingkungan sosial pada saat ini, di era kemajuan ilmu pengetahuan dan tekhnologi memberi dampak psikologis yang luar biasa, bukan hanya faktor fisik saja yang terkena imbasnya, tetapi faktor mental emosional bahkan lebih rentan. Kondisi suasana kemodernan dan kehidupan di kota-kota besar yang diwarnai kemacetan, polusi udara, kebisingan dan kerunyaman ruang hidup yang makin menyempit memberikan tekanan luar biasa, sehingga

${ }^{1}$ Pada masyarakat Barat modern atau masyarakat yang mengikuti peradaban Barat yang sekuler, solusi yang ditawarkan untuk mengatasi problem kejiwaan biasanya dilakukan dengan menggunakan pendekatan psikologi, dalam hal ini kesehatan mental (mental health). Sedangkan pad masyarakat Islam karena mereka (kaum muslimin) pada awal sejarahnya tidak mengalami problem psikologis seperti yang dialami oleh masyaraka Barat, maka solusi yang ditawarkan lebih bersifat religius-spritual, yakni tasauf atau akhlak. Keduanya menawarkan solusi bahwa manusia itu akan memperoleh kebahagiaan pada zaman apapapun, jika hidupnya bermakna. Pertanyaan yang kemudian muncul ialah bagaimana hidup bermakna pada zaman modern itu. (Ahmad Mubarak, Jiwa Dalam Al-Quran, Solusi Krisis Keruhanian Manusia Modern, Paramadina Jakarta, 2000, h. 14)

${ }^{2} \mathrm{Ahmad}$ Mubarak, Jiwa Dalam Al-Quran, Solusi Krisis Keruhanian Manusia Modern, Paramadina, Jakarta, 2000, h. 13.

${ }^{3}$ Dalam al-Quran untuk mengungkap pernyataan maaf biasanya menggunakan term al-'Afw (Maaf). Kata al-'afw terulang dalam Al-Quran sebanyak 34 kali. Kata ini pada mulanya berarti berlebihan (Q.S al-Baqarah/2 19) Term lain yang senada, semakna, dan masih berkaitan dengan maa digunakan juga term al-Shafh (Lapang Dada). Kata al-shafh dalam berbagai bentuk terulang sebanyak delapan kali dalam Al-Quran. Kata ini pada mulanya berarti lapang. Maka dari sini, al-shafh dapat diartikan kelapangan dada dan berjabat tangan dinamai mushafahat, karena melakukannya menjadi perlambang kelapangan dada. Dari delapan kali bentuk al-shafh yang dikemukakan, ternyata ada empat kali di antaranya didahului oleh perintah untuk memberi maaf, yaitu Q.S at-Thaghabun/64: 14, Q.S an-Nur/24: 2, Q.S, al-Ma-idah/5:13, dan Q,S, al-Baqarah/2:109. 
Rohimin | Al-Quran dan Psikoterapi Elaborasi Deduktif 3

kondisi mental emosional manusia senantiasa tegang, memberontak, dan bergejolak. Kondisi masyarakat yang semacam ini cenderung mengarah pada trend budaya hedonisme, materialisme, dan individualisme. Sehingga menyebabkan kompetisi yang semakin tidak sehat. Kemerosotan ahlak, moral atau etika pada masyarakat menyebabkan iklim sosial yang kurang sehat dan tidak kondusif.

Ketegangan kehidupan sosial ekonomi, politik, dan bahkan beragama bisa juga menyebabkan berbagai kalangan usia mengalami tekanan mental emosional, mulai dari gejala dan keadaan yang paling ringan sampai kepada yang paling berat. Oleh karena itu, tidak heran jika beragam kompensasi atau pelarian pun bermunculan, mulai dari narkoba, tawuran, persekusi, selingkuh dan berbagai penyimpangan lainnya. Keadaan lain yang menjadi pemicu gangguan mental emosional ialah adanya kesulitan pribadi, baik yang bersifat subyektif atau pun obyektif. Arena kehidupan itu penuh dinamika dan tantangan, setiap orang harus menjalaninya. Namun ada yang piawai, biasa saja, dan ada yang tidak mampu beradaptasi. Di samping itu ada juga orang yang dengan karakter unggulnya mampu mengatasi berbagai kesulitan dan persoalan, sementara itu ada juga orang yang mengeluh dan berkeluhkesah, tidak berdaya dalam menghadapi beragam ujian tersebut.

Terdapat beberapa keadaan mental yang secara khusus perlu mendapat perhatian, yaitu "sehat mental dan "sakit mental". Sehat mental secara umum dapat diartikan sebagai kondisi mental yang tumbuh dan didasari motivasi yang kuat ingin meraih kualitas diri yang lebih baik, baik dalam kehidupan keluarga, kehidupan kerja atau profesi, maupun sisi kehidupan lainnya. Orang yang disebut memiliki mental tidak sehat ialah orang yang meskipun secara potensial memiliki kemampuan, tetapi tidak punya keinginan dan usaha untuk mengaktualisasikan potensinya itu secara optimal. Sementara orang yang disebut sakit mental adalah orang yang secara mental memiliki berbagai macam unsur yang saling bertentangan dan dengan demikian, sering merusak atau menghambat, sehingga perilakunya tidak menentu. ${ }^{4}$

Selanjutnya dijelaskan, Pribadi sehat adalah pribadi yang mampu mengatur diri dalam hubungannya dengan diri sendiri, orang lain dan lingkungan sosial. Al-Quran di samping menerangkan pribadi yang sehat adalah pribadi yang mampu mengatur diri dalam hubungannya terhadap diri sendiri, orang lain, dan lingkungan sosial, juga menerangkan pribadi yang mampu mengatur diri dalam hubungannya dengan Allah Swt. ${ }^{5}$

Sebagai dampak dari ketidak-mampuan manusia dalam meredam gangguan mental emosional, maka berbagai gangguan yang bersifat mental emosional, bahkan fisik pun bermunculan. Kenyataan ini bisa diduga bahwa sebagian orang yang mengalami gangguan berbagai penyakit fisik, sebenarnya dipicu juga oleh gangguan kesehatan jiwa. Sebagai contoh, sebagian penderita gangguan penyakit maag atau penderita tukak (radang) lambung, sebenarnya bukan disebabkan oleh lambungnya yang bermasalah, namun lebih disebabkan oleh gangguan mental emosional. Oleh karena itu, al-Qur'an hadir sebagai terapi bagi psikologis manusia yang mengalami suasana demikian. Demikian pula halnya dengan orang yang menahan untuk memberi maaf atau tidak mau menjadi pemaaf dan meminta maaf dalam tindakan dan suasana salah. Maka keadaan seseorang semacam ini, tidak menutup kemungkinan akan menyebabkan penyakit fisik yang lain. Maka tawaran psikoterapi maaf dan meminta maaf menjadi urgen.

Di sisi lain, sebenarnya kadangkala secara psikologis banyak ajaran agama yang sulit diterima, dipahami, diterangkan, dan dipraktekan tanpa ada dukungan psikologis dan medis ke- 
4

dokteran, seperti larangan agama untuk mengkonsumsi narkoba, tuak dan minuman lain yang memabukkan, namun ilmu kedokteran sangat berkontribusi besar dalam menerangkan bahayanya, sehingga ajaran agama lebih mudah untuk diterima dan memiliki dukungan rasional atas larangannya. Karena dari analisis ilmiah rasional, apa yang dilarang oleh agama selalu mengandung bahaya bagi pelakunya, sedangkan yang diperintahkan selalu mengandung kebaikan. Manusia yang sehat mentalnya paling tidak ada beberapa kriteria, yaitu sehat secara fisik, sehat secara psikologis, sehat secara sosial, dan sehat secara spiritual.

Berangkat dari beberapa asumsi dan berbagai persoalan di atas, maka tulisan ini berupaya mengelaborasi, bagaimana deduksi al-Quran tentang pengobatan dan penyembuhan dengan trapi psikologi melalui Kitab Suci (al-Quran). Untuk mendapatkan elaborasi yang akurat maka dibutuhkan data-data deduksi al-Quran melalui penegasan ayat dan hasil integrasi pemahaman ayat dengan ilmu psikologi dan praktek psikoterapi seperti yang dilakukan oleh para pelaku rukyah yang menggunakan terapi alQuran dan ulasan tafsir terhadap pemahaman ayat-ayat yang berkaitan dengan persoalan manusia. Pendekatan dengan religiusitas agama dan Kitab Suci (al-Quran) ini dijadikan sebagai media terapi dalam trapi psikologi. Dalam pembahasan tulisan ini penulis membedakan antara psikoterapis, psikologi, dan psikiater. Pembedaan ini dilakukan karena ketiga identitas atau profesi tersebut dianggap berbeda dalam pekerjaan. Selain itu, untuk memfokuskan pada terapi psikologi melalui media Kitab Suci ( al-Quran ) diupayakan melalui deduksi dan narasi pemahaman ayat-ayat yang berkaitan.

\section{Pembahasan}

\section{Peranan Al-Qur'an Sebagai Terapi Psikologis}

Baharuddin, ${ }^{6}$ dalam disertasinya yang ber- judul, "Paradigma Psikologi Islami, Studi tentang elemen Psikologi Dari Al-Quran”, yang kemudian diterbitkan menjadi buku oleh Pustaka Pelajar, Yogyakarta. ${ }^{7}$ Dengan judul yang sama menegaskan, bahwa terdapat sebelas istilah kunci yang digunakan al-Quran dalam menjelaskan manusia, yaitu : al-insan, al-ins, al-basyr, ar-ruh, al-Qalb, al-'aql, an-nafs, bani adam, an-nas, al-inas, dan al-fitrah.

Bertolak dari pengertian psikologi sebagai ilmu yang menelaah prilaku manusia, para ahli psikologi umumnya berpandangan bahwa kondisi ragawi, kualitas kejiwaan, dan situasi lingkungan, merupakan penentu-penentu utama prilaku dan corak kepribadian manusia. Diterminan tri-dimensional organo-biologi, psikoedukasi, dan sosio-kultural ini dapat dikatakan dianut oleh semua ahli di dunia psikologi dan psikiatri. Dalam hal ini unsur ruhani sama sekali tidak masuk hitungan, karena dianggap termasuk dimensi kejiwaan dan merupakan penghayatan subyektif semata-mata. ${ }^{8}$

Pandangan sekularistik di atas menggambarkan bahwa manusia dalam pandangan psikolgi sekuler menempatkan manusia sebagai pusat dari segala pengalaman dan relasi-relasinya serta penentu utama segala peristiwa yang menyangkut masalah manusia dan kemanusiaan. Pandangan ini mengangkat derajat manusia ke tempat teramat tinggi, manusia seakan-akan prima causa yang unik, pemilik akal budi yang sangat hebat, serta memiliki pula kebebasan penuh untuk berbuat apa yang dianggap baik dan sesuai baginya. Pandangan semacam ini dalam filsafat manusia sering disebut dengan "Antroposentrisme", yaitu paham bahwa manusia adalah spesies paling pusat dan penting daripada spesies hewan atau penilaian kenyataan melalui sudut pandang manusia yang eksklusif.

Secara deduktif al-Quran menyatakan dirinya dan memberi tahu kepada manusia bahwa dia hadir sebagai penyembuh, terutama terh- 
Rohimin | Al-Quran dan Psikoterapi Elaborasi Deduktif

adap penyakit-penyakit yang berada di dalam dada atau penyakit mental. Karena al-Quran hadir sebagai pembelajaran, penyembuh, petunjuk, dan rahmat. Bilamana penyakit kejiwaan atau penyakit mental dan penyakit sosial dalam pandangan psikolog bisa menyebabkan penyakit fisik, maka sesungguhnya al-Quran juga bisa menyembuhkan penyakit fisik. Selain memiliki efek menenangkan dan menggetarkan jiwa, alQur'an juga memiliki efek preventif, kuratif, dan terapeutik terhadap berbagai penyakit kejiwaan, spiritual hingga fisik.

Banyak nama dan identitas yang diberikan pada al-Quran, penamaan dan identitas ini sekaligus menunjukkan kepada posisi, peran, dan fungsi yang bisa diberikan oleh al-Quran itu sendiri, sesuai dengan arti dan muatan dari nama yang diberikan. Al Qur'an adalah obat mujarab untuk hati. Al Qur'an menjadi obat bagi hati yang terkena syubhat (racun pemikiran) dan syahwat (nafsu jelek untuk maksiat). Dalam Al Qur'an terdapat penjelas, di mana kebatilan dapat dimusnahkan oleh kebenaran. Penyakit syubhat yang merusak bisa hilang (pergi) karena adanya ilmu dan keinginan (yang baik), di mana hakikat sesuatu begitu jelas karenanya. Dalam Al Qur'an terdapat berbagai hikmah yang bisa dipetik, terdapat berbagai nasehat yang baik untuk memotivasi dalam beramal dan menakut-nakuti dari berbuat kejelekan. Dalam Al Qur'an juga terdapat kisah-kisah yang bisa diambil 'ibrah (pelajaran) sehingga hati pun menjadi baik. Al Qur'an begitu memberi semangat hati pada hal-hal yang bermanfaat dan memperingatkan pula dari halhal yang membahayakan. Akhirnya, hati semakin cinta pada kebenaran dan benci pada kebatilan. Padahal sebelumnya bisa jadi hati sangat ingin berbuat kebatilan dan benci pada kebenaran. $\mathrm{Al}$ Qur'an sungguh bisa menghilangkan penyakit yang dapat mengantarkan pada keinginan-keinginan jelek (rusak) hingga baiklah hati. Keinginannya menjadi baik dan ia pun kembali pada fithrahnya yang telah ditabiatkan untuknya sebagaimana badan kembali pada tabi'atnya. Hati akan semakin hidup dengan adanya iman dan Al Qur'an. Sebagaimana badan semakin hidup dengan sesuatu yang dapat menumbuhkan dan menguatkannya. Suburnya hati itulah semisal dengan tumbuhnya badan. Hati bukanlah subur dan hidup dengan nyanyian, namun dengan Kalamullah. Inilah cara menyuburkan dan menenangkan hati, yaitu dengan mendengar, membaca, menghafalkan dan mentadabburi (merenungkan) Al Qur'an.

Pembicaraan al-Quran sebagai syifâ' (obat, penyembuh atau penawar) terhadap penyakit, sampai saat ini masih menjadi perbicangan akademik yang menarik. Apalagi, ketika wacana itu dilanjutkan dengan fungsi al-Quran sebagai rahmat (karunia) Allah. Pembicaraan akademik biasanya seputar, apakah al-Quran memiliki kompetensi kegunaan yang demikian dan apakah nilai dan substansi kegunaannya bersifat absolut (mutlak) atau nisbi (relatif). Dalam kenyataan iInilah kemudian memunculkan para mufassir al-Quran untuk menjelaskannya dengan berbagai ragam pendekatan dan metode. Namun bila dicermati, semuanya bermuara pada efektivitas kegunaan al-Quran sebagai syifâ' dan rahmah dan sangat bergantung pada manusia yang mengharapkannya. Apakah yang bersangkutan telah memenuhi persyaratan utama untuk memerolehnya atau belum. Semakin terpenuhi persyaratan utamanya, maka semakin mungkin seseorang akan memeroleh syifâ' dan rahmah dari Allah melalui al-Quran, begitu juga sebaliknya. ${ }^{10}$ Selain memiliki efek menenangkan dan menggetarkan jiwa, al-Qur'an juga memiliki efek preventif, kuratif, dan terapeutik terhadap berb-

${ }^{8}$ Hanna Djumhana Bastaman, Integrasi Psikologi Dengan Islam, Menuju Psikologi Islami, Yayasan Insan Kamil bekerjasama dengan Pustaka Pelajar, Yogyakarta, 2005, h. 49

${ }^{9}$ Lihat Q.S. Yunus/10 : 57) dan Q.S al-Isrâ'/17: 82. "Hai manusia, Sesungguhnya telah datang kepadamu pelajaran dari Tuhanmu dan penyembuh bagi penyakit-penyakit (yang berada) dalam dada dan petunjuk serta rahmat bagi orang-orang yang beriman". 
agai penyakit kejiwaan, spiritual hingga penyakit fisik.

\section{Pendekatan Psikoterapi}

Psikoterafi adalah proses profesional dengan kode etik tertentu. ${ }^{11}$ Proses psikoterafi adalah proses formal interaksi antara dua pihak atau lebih, yang satu adalah profesional penolong dan yang lain adalah "petolong" (orang yang ditolong) dengan catatan bahwa interaksi itu menuju pada perubahan atau penyembuhan. Perubahan itu dapat berupa perubahan rasa, fikir, prilaku, kebiasaan yang ditimbulkan dengan adanya tindakan profesional penolong dengan latar ilmu prilaku dan teknik-teknik usaha yang dikembangkannya. Hanya saja batasan seperti ini tidak selalu tepat karena ada terapi yang tidak termasuk di dalamnya.

Suatu manifestasi dari timbulnya gangguan atas kelainan pada diri seorang yang sehat disebut penyakit. Timbulnya penyakit pada individu dipengaruhi oleh tiga faktor utama, yaitu; Pertama, host atau penjamu, yakni suatu hal yang terdapat pada diri individu yang dapat mempengaruhi timbulnya suatu penyakit. Yang termasuk faktor ini adalah keturunan (gen), sistem imun, usia, jenis kelamin, ras, status perkawinan, pola hidup dan sebagainya. Kedua, agent (bibit penyakit) suatu substansi yang kehadiran dan ketidakhadirannya bisa menimbulkan suatu penyakit. Ada dua jenis substansi ini, yaitu biotik (makhluk hidup) dan abiotik (benda mati), misalnya debu, udara, dan zat kimia. Ketiga, Lingkungan, yakni seluruh kondisi di luar individu yang mempengaruhi kehidupan dan perkembangan organisme baik lingkungan fisik maupun non-fisik seperti sosial budaya. ${ }^{12}$

Lebih lanjut Sholeh menegaskan secara ilustratif, "Ketiga faktor ini saling mempengaruhi dalam pencetusan suatu penyakit. Hubungan ketiganya dapat digambarkan seperti timbangan, di mana penjamu (P), bibit penyakit(B) adalah tuasnya, sedangkan lingkungan (L) adalah penumpunya. Individu dalam keadaan sehat, apabila tuas, penjamu dan bibit penyakit lebih dapat menarik dari lingkungan dan penjamu".13

Dalam konteks psikologi Islam biasanya dalam diri manusia, penyakit bisa bisa bersumber dari tiga faktor utama, yakni, 1. Sakit fisik dari pencernaan makanan, minuman, asupan, dan suntikan. 2. Sakit Psikis atau kejiwaan 3. Sakit karena gangguan luar, seperti Jin, Sihir, dan 'ain. ( dalam terminologi Islam, penyakit 'ain biasanya diartikan sebagai penyakit yang disebabkan oleh pengaruh buruk pandangan mata, yaitu pandangan mata yang disertai rasa takjub atau bahkan iri dan dengki terhadap apa yang dilihatnya, terjadi keterpengaruhan yang tidak selektif).

Dalam hal deteksi, pengobatan, dan penyembuhan pendekatan Psikoterapis, Beda Dengan pendekatan Psikolog dan Psikiater. Mereka semua beda dalam pekerjaannya. Psikoteapis adalah seseorang yang melakukan terapi untuk mengatasi gangguan mental dengan metode yang teruji dan sesuai dengan prinsip ilmu psikologi modern. Kegiatan seorang psikoterapis adalah menyembuhkan gangguan pikiran, mengatasi masalah perasaan, mengubah perilaku, merenovasi kepribadian, membantu perkembangan diri seseorang dan memperbaiki hubungan satu orang dengan orang lainnya. Seorang psikoterapis bisa membantu mengatasi fobia, trauma, depresi, kecemasan, stress, rasa minder, perilaku obsesif kompulsif, halusinasi, gangguan tidur, kebiasaan buruk dan berbagai masalah psikologis lainnya. Seorang psikoterapis juga bisa membatu mengembangkan kualitas pribadi seseorang, meningkatkan kepercayaan diri, meningkatkan

${ }^{10} \mathrm{Al}$-Quran menegaskan bahwa, "Dan Kami turunkan dari al-Quran suatu yang menjadi obat (penawar) dan rahmat bagi orang-orang yang beriman dan al-Quran itu tidaklah menambah kepada orang-orang yang zalim selain kerugian." Lihat Q.S al-Isrâ'/17: 82.

${ }^{11}$ M.A. Subandi (ed), Psikoterafi, Pendekatan Konvensional Dan Kontemporer, Pustaka Pelajar bekerja sama dengan Unit Publikasi Fakultas Psikologi UGM, Yogyakarta, 2002, h. 5.

${ }^{12} \mathrm{Moh}$. Sholeh Imam Musbikin, Agama Sebagai Terapi, Telaah menuju Ilmu Kedokteran Holistik, Pustaka Pelajar, Yogyakarta, 2005, h. 180 
Rohimin | Al-Quran dan Psikoterapi Elaborasi Deduktif

kemampuan membuat keputusan dan membantu menciptakan karakter pribadi yang sesuai dengan keinginan seseorang. Artinya setiap orang, baik itu psikolog, psikiater, dokter umum, guru, pedagang, kiyai, pendeta atau siapapun yang bisa mengatasi masalah psikologis orang lain, maka orang tersebut bisa disebut Psikoterapis. Oleh karena itu untuk menjadi psikoterapis bisa berasal dari segala macam profesi. Seorang Psikolog dan Psikiater juga bisa menjadi dan disebut Psikoterapis ketika mereka mempraktekkan psikoterapi. ${ }^{14}$

Setiap orang pada dasarnya bisa menjadi psikoterafis setelah melalui pelatihan tertentu dan memenuhi syarat-syarat seperti, mempunyai pengetahuan mengenai dasar-dasar ilmu psikologi dan psikopatologi (ilmu tentang penyakit mental), serta proses-proses mental yang terjadi pada manusia. Kemampuan ini bisa diperoleh melalui jalur akademik perkuliahan, pelatihan dan kursus-kursus singkat, maupun membaca, memahami dan mendalami secara otodidak. Persyaratan lain ada kemampuan untuk dapat menarik suatu kesimpulan tentang adanya keadaan mental pasien yang telah diperiksa, misalnya didapat melalui pengetahuan dan pengalaman. Seorang psikoterapis haruslah merupakan pendengar yang cermat bagi pasiennya, bahkan dia tidak hanya mendengar, tapi juga mampu memahami apa yang tersurat ataupun yang tersirat dibalik kata-kata yang diucapkan pasien. Dengan mendengar secara cermat dan dibekali oleh pengetahuan yang cukup seorang psikoterafis akan mendapat gambaran tepat tentang pasien-pasien yang diwawancarai atau diperiksa.

Dalam menjalani aktivitas psikoterafi, seorang psikoterapis sejatinya memiliki kemampuan berkomunikasi dan interaksi yang baik, mampu menjalin keakraban, persuasif secara humanis dan psikologis dan tahu tentang cara dan mement untuk memberi nasihat yang tepat, bisa memberikan teladan dan penuh rasa empati yang bisa memahami perasaan orang lain, serta memiliki kemampuan untuk menghibur dan kemampuan menginterpretasi semua gejala dan kenyataan yang sedang terjadi. Seorang psikoterafis juga memiliki keterampilan dalam menerapkan teknik dan metode penanganan masalah mental pasien. Oleh karena itu, ketrampilan dalam menerapkan teknik psikoterapi begitu urgen bagi seorang psikoterfis.

Dalam psikoterapi berwawasan Islam fungsi terafis adalah sebagai pembimbing (mursyid) bagi klien (mursyad bih) untuk mencapai tarap kehidupan yang lebih tinggi dan sempurna sesuai dengan kapasitas manusia dan fitrah kemanusiaannya. Sebagai mursyid ia bertanggung jawab pada fungsi tiga unsur kehidupan manusia, yaitu membimbing jasmani klien agar terhindar dari segala perbuatan yang mengotori jasad manusia, merusak hal-hal berharga dalam fisik dan biologis manusia dengan prinsip preventif terhadap lima hal yaitu, 1. hifzh al-din (memelihara ketentuan ibadah dari agama), 2. hifzh nafsi (memelihara kebersihan jiwa), 3. hifzh al-nasal (memelihara keturunan), 4. hifzh al-mal (memelihara harta), dan 5. hifzh al-'aql (memelihara yang merusak akal). ${ }^{15}$

Seorang psikoterafis hendaklah memiliki sikap dan kepribadian yang tepat, orang yang sehat secara mental dan berkarakter kuat, percaya diri, mudah bergaul, tidak memihak siapapun, dan optimis dan senang melakukan pekerjaan pada profesinya. Ketika seseorang psikoterapi melakukan psikoterapi hanya karena tuntutan

${ }^{13}$ Moh. Sholeh Imam Musbikin, Agama Sebagai Terapi............h. 181.

${ }^{14}$ Kalau psikolog adalah lulusan psikologi dan dengan standar tertentu sudah disahkan sebagai psikolog oleh lembaga psikologi. Bidang kegiatan mereka mulai dari menyediakan jasa psikotes, konseling dan terapi. Mereka menerapkan metode-metode terapi berdasarkan teori-teori psikologi yang diajarkan di perkuliahan. Psikolog tidak dilatih dan tidak diperbolehkan memberikan resep obat kepada pasiennya. Sementara psikiater adalah dokter yang mengambil spesialitasi dibidang psikiatri atau kejiwaan. Psikiater biasa disebut Dokter Jiwa. Psikiater biasanya menangani gangguangangguan jiwa yang serius sebagaimana yang diderita oleh pasien-pasien rumah sakit jiwa. Karena sebenarnya Psikiater adalah dokter, maka dia boleh memberikan obat psikoaktif, obat penenang, anti depresan, obat tidur dan ssebagainya kepada pasiennya. 
kerja smata bukan melakukan psikoterapi sebagai beban, sebab kalau terasa beban tidak ada totalitas dalam menangani pasiennya. Proses psikoterapi adalah hubungan kedekatan personal antara pskoterpis dan pasien. Oleh karena itu, psikoterpis yang baik adalah psikoterapis yang benar-benar menyenangi pekerjaannya sebagai psikoterpis. Seorang psikoterapis yang profesional sejatinya tidak berhenti belajar dan selalu memperbaharui pengetahuan yang dapat memperkaya wawasannya tentang dinamika manusia. Sebab pada kenyataannya kalau hanya mengandalkan pengetahuan yang diperoleh di bangku kuliah saja tidaklah cukup. Selain memenuhi beberapa point di atas, seorang psikoterapis sebaiknya punya hak dan legalitas untuk melakukan psikoterapi. Hak dan legalitas ini biasanya ditandai dengan adanya surat izin dari instansi terkait. Sebab dewasa ini, ditemui banyak orang yang menawarkan terapi atau pengobatan tanpa punya legalitas hukum.

\section{Psikoterafi Memaaf Dan Meminta Maaf}

DI era modern ini, persilangan-persilangan kehidupan manusia dalam aktivitasnya semakin komplek, kesalahan dengan orang lain dan bahkan kesalahan terhadap dirinya sendiri serta pergulatan emosional kemarahan semakin meningkat. Ketidaksabaran dalam menjalani kehidupan dalam dunia nyata (ofline) atau luring dan kehidupan dalam dunia maya (online) atau daring serta kehidupan dalam media cetak dan media sosial semakin menimbulkan persoalan. ${ }^{16}$

Oleh karena itu maaf dan meminta maaf semakin urgen dan bisa menjadi salah satu tawaran psikoterafi. Kemajuan yang telah merambah dalam berbagai aspek kehidupan manusia, baik sosial, ekonomi, budaya dan politik, mengharuskan individu untuk beradaptasi terhadap perubahan-perubahan yang terjadi secara cepat dan pasti. Padahal dalam kenyataannya tidak semua individu mampu melakukannya sehing- ga yang terjadi justru masyarakat atau manusia yang menyimpan banyak problem.

Dalam kenyataannya tidak semua orang mampu untuk beradaptasi, akibatnya adalah individu-individu yang menyimpan berbagai problem psikis dan fisik. Dengan demikian dibutuhkan cara efektif untuk mengatasinya. Oleh karena itu Islam melalui Kitab Sucinya hadir sebagai penyembuh, terutama terhadap penyakitpenyakit yang berada di dalam hati atau penyakit mental. Berbicara masalah solusi, kini muncul kecenderungan masyarakat untuk mengikuti kegiatan-kegiatan spiritual (tasawuf). Tasawuf sebagai inti ajaran Islam muncul dengan memberi solusi dan terapi bagi problem manusia dengan cara mendekatkan diri kepada Allah sebagai penciptanya. Selain itu berkembang pula kegiatan konseling yang memang bertujuan membantu seseorang menyelesaikan masalah kompleksitas kehidupannya. Dalam terminologi agama, khususnya agama Islam selalu ada panduan dan solusi terhadap masalah, Karena semua masalah pasti ada penyelesaiannya serta segala penyakit pasti ada obatnya. Peluang tasawuf sebagai kekuatan spritual (spritual power) dalam menangani penyakit-penyakit psikologis atas segala problem manusia, semakin terbentang lebar, terlebih lagi di era modern ini. Maka pada masyarakat Islam, karena mereka (kaum muslimin) pada awal sejarahnya tidak mengalami problem psikologis seperti yang dialami masyarakat Barat, maka solusi yang ditawarkan lebih bersifat religius-spritual, yakni tasauf atau akhlak. Keduanya menawarkan solusi bahwa manusia itu akan memperoleh kebahagiaan pada zaman apapapun, jika hidupnya bermakna. Atas dasar pemikiran ini, maka sikap pemaaf dan memberi maaf sebagai bagian dari akhlak diyakini dapat dijadikan sebagai psikoterapi di era modernmilenial.

Secara deduktif dan fungsional al-Quran menegaskan agar menjadi diri dan pribadi yang pe- 
maaf sekalipun pemaafan itu tidak diminta dan dituntut, di dalam al-Quran disebut secara fungsional dengan identitas pemaaf (al-'afin). ${ }^{17}$

Atas dasar penegasan ini maka memaafkan merupakan sikap mulia yang sangat dianjurkan dalam agama Islam, sesulit dan seberat apapun manusia mengalami dampak akibat kesalahan yang dilakukan orang lain, karena itu al-Quran menegaskan dan memerintahkan setiap hambanya untuk melapangkan dada terhadap kesalahan orang lain dan sesama. ${ }^{18}$

Menjadi pemaaf dan pemberi maaf serta berlapang dada ketika diminta maaf serta berusaha meminta maaf sekaligus memberi terapi pada diri sendiri agar tidak menjadi beban psikologis terhadap diri sendiri dan orang lain. Karena bisa saja kekesalan pada diri sendiri akan menjadi penyakit mental dan juga bisa berdampak pada penyakit fisik (pisikosomatis). Berkenaan denga sikap agar senantiasa memberi maaf ini dalam al-Quran ditegaskan, "Dan janganlah orang-orang yang mempunyai kelebihan dan kelapangan di antara kalian bersumpah bahwa mereka (tidak) akan memberi (bantuan) kepada kaum kerabat(nya), orang-orang yang miskin dan orangorang yang berhijrah di jalan Allah. Dan hendaklah mereka memberi maaf dan berlapang dada.

${ }^{17}$ Lihat Q.S. Ali Imran/3 : 133-136. Dalam ayat lain dinyatakan juga jadilah pemaaf dan suruhlah orang berbuat makruf, serta jangan pedulikan orang-orang yang bodoh. (Q.S. al A'raf/7: 199), Q.S. an-Nur/24: 22).

${ }^{18}$ Untuk melihat narasi dan deduksi al-Quran tentang maaf dan memberi maaf penulis melacak melalui term al-'Afw (Maaf), Kata al-'afw terulang dalam Al-Quran sebanyak 34 kali. Kata ini pada mulanya berarti berlebihan, seperti : "Mereka bertanya kepadamu tentang hal yang mereka nafkahkan (kepada orang). Katakanlah, "al-'afw" (yang berlebih dari keperluan), seperti yang terdapat dalam Q.S al-Baqarah/2:219, dan untuk mendapatkan uraian aplikasi yang lebih mendalam penulis juga menggunakan term, al-Shafh (Lapang Dada), karena dua term ini saling berkaitan.Kata al-shafh dalam berbagai bentuk terulang sebanyak delapan kali dalam Al-Quran. Kata ini pada mulanya berarti lapang.Halaman pada sebuah buku dinamai shafhat karena kelapangan dan keluasannya. Dari sini, al-shafh dapat diartikan kelapangan dada. Berjabat tangan dinamai mushafahat karena melakukannya menjadi perlambang kelapangan dada. Dari delapan kali bentuk al-shafh yang dikemukakan, empat di antaranya didahului oleh perintah memberi maaf. Q.S at-Thaghabun/64: 14, Q.S an-Nur/24: 22, Q.S. al-Maidah/5: 13. Dan Q.S. al-Baqarah/2: 109 .

${ }^{19}$ Lihat Q.S. an-Nur/24: 22

${ }^{20}$ Lihat Q.S. al-Hujurat/49: 10, "Sesungguhnya orang-orang yang beriman bersaudara, karena itu damaikanlah antara kedua saudaramu (yang berselisih), dan bertakwalah kepada Allah agar kamu mendapat rahmat".
Apakah kalian tidak ingin Allah mengampuni kalian? Dan Allah Maha Pengampun lagi Maha Penyayang" ${ }^{19}$

Terkait ayat tersebut dapat ditarik pemahaman bahwa orang yang saleh dan memiliki kekayaan dalam suatu komunitas hendaknya tidak bersumpah untuk tidak memberikan derma kepada kerabat, orang miskin, orang yang berada di jalan Allah dan orang yang berhak menerima infak lainnya, hanya karena alasan-alasan yang bersifat pribadi seperti dengan sengaja menyakiti. Sebaliknya, mereka hendaknya memaafkan dan tidak membalas keburukan yang ditimpakan. Apabila seseorang ingin agar Allah memaafkan kesalahan-kesalahannya, maka hendaknya tetap berbuat baik kepada orang yang mungkin pernah melakukan kesalahan.

Ayat ini diturunkan ketika sahabat Abu Bakar al-Siddiq bersumpah untuk tidak lagi memberikan bantuan ekonomi kepada kerabatnya yang bernama Mastah bin Utsatsah lantaran terlibat kasus tuduhan bohong (hadis al-ifki) terhadap istri Rasulullah Saw, Aisyah r.a. Ayat di atas menegaskan bahwa memaafkan merupakan sikap mulia yang hendaknya dimiliki setiap orang, karena Allah sendiri maha pemberi maaf dan menyayangi hamba-Nya. Pemberian maaf sebagaimana ditekankan dalam ayat ini tidak harus menunggu permintaan maaf. Substansi memaafkan berdasarkan ayat tersebut adalah berlapang dada dan membuka pintu maaf selebar-lebarnya kepada orang lain dengan kesadaran penuh bahwa kesalahan merupakan suatu keniscayaan yang pasti pernah dilakukan oleh setiap manusia. Perintah memaafkan dalam ayat di atas juga mesti dipahami bahwa mengampuni kesalahan orang lain harus disertai keikhlasan, artinya melapangkan dada dan menyadari bahwa seluruh ganjalan yang selama ini terbersit dalam hati telah hilang sepenuhnya, sehingga yang tersisa adalah optimisme untuk menatap masa depan yang lebih damai dan tenteram. Enggan memaaf- 
kan kesalahan orang lain, saudara atau kerabat, apalagi disertai sumpah serapah yang bisa mengancam keutuhan jalinan persaudaraan tidaklah mencerminkan sikap seorang muslim sejati. Oleh sebab itu islah, rekonsiliasi atau perbaikan hubungan antar pihak-pihak yang berselisih sangat dianjurkan dalam Islam. Dalam konteks rekonsiliasi antar pihak yang berselisih. ${ }^{20}$

Melalui ayat ini, al-Quran menegaskan bahwa manakala di antara sesama manusia dalam istitusi komunitas apapun terjadi perselisihan dan persengketaan yang bisa merusak hubungan antar sesama, maka rekonsiliasi di antara dua belah pihak, yaitu pihak yang pernah melakukan kesalahan dan pihak yang menjadi korbannya harus diupayakan melalui terapi maaf dan memita maaf. Perbaikan hubungan antara pihak-pihak yang bertikai tidak hanya dimuliakan tetapi juga menjadi harapan bagi masyarakat secara luas sesuai dengan alamiah manusia. Hal itu karena setiap manusia pada prinsipnya membutuhkan perdamaian dan ketenangan dalam hidupnya. Pada akhirnya, memaafkan dan meminta maaf hendaknya menjadi kesadaran bersama bahwa setiap kejadian di muka bumi ini telah ditakdirkan oleh Allah Swt. Setiap peristiwa di dunia ini bersifat kudrati yang tak seorang pun bisa menolaknya. Maka dari itu, seperah apa pun kejadian yang menimpa, kita harus menjadikannya sebagai pembelajaran, karena di balik semua kejadian di muka bumi ini pasti ada hikmah yang bisa kita ambil sebagai pembelajaran dan masih dalam batas kemampuan manusia. ${ }^{21}$

Di lingkungan keluarga, agar suasana dan lingkungan keluarga menjadi lebih sakinah, yang diselimuti mawaddah dan rahmah, terlebih lagi dalam skala keluarga inti maka manakala masing-masing anggota keluarga memiliki sifat pemaaf dan meminta maaf bisa memberi terafi preventif dalam keluarga, memaafkan itu dianggap sebagai akhlak utama. Dalam al-Quran dinyatakan, "Wahai orang-orang yang beriman,
Sesungguhnya di antara istri-istrimu dan anakanakmu ada yang menjadi musuh bagimu, maka berhati-hatilah kamu terhadap mereka; dan jika kamu maafkan dan kamu santuni serta ampuni (mereka), maka sungguh, Allah Maha Pengampun, Maha Penyayang".22

Demikian pula halnya dalam kehidupan berbangsa, bernegara, dan bermasyarakat. Ketika ada peminta-minta diberi, tetapi kemudian disertai dengan ungkapan yang menyakitkan, maka memaafkan jauh lebih utama. Dalam ajaran agama Perkataan yang baik dan pemberian maaf lebih baik daripada sedekah yang diiringi dengan tindakan yang menyakiti. ${ }^{23}$

Bila kita melihat keteladanan yang diberikan Rasulullah tentang pemaafan, ketika dia pernah akan dibunuh oleh orang kafir pada waktu ketika dia tidur sendirian dibawah pohon, ketika tiba-tiba pedang orang kafir jatuh dan diambil oleh Nabi lalu dimaafkan, betapa sikap pemaaf Rasulullah itu dapat memberi terapi psikologis terhadap orang kafir tersebut. Dalam al-Quran digambarkan, "Maka berkat rahmat Allah engkau (Muhammad) berlaku lemah lembut terhadap mereka. Sekiranya engkau bersikap keras dan berhati kasar, tentulah mereka menjauhkan diri dari sekitarmu. Karena itu maafkanlah mereka dan mohonkanlah ampunan untuk mereka, dan bermusyawarahlah dengan mereka dalam urusan itu. Kemudian, apabila engkau telah membulatkan tekad, maka bertawakallah kepada Allah. Sungguh, Allah mencintai orang yang bertawakal .

Psikoterafi memaaf dan meminta maaf merupakan bagian dari psikoterapi tasauf. Psikoterapi tasauf adalah sebuah upaya psikoterapi yang menggabungkan dua disiplin ilmu dan pendekatan, yaitu Tasawuf dan Psikoterapi . Sebagai satu disiplin ilmu Tasawuf Psikoterapi menggabungkan kedua ilmu tersebut untuk mengkaji topiktopik yang terkait dengan masalah kejiwaan melalui pendekatan psikologis dan sufistik. 
Rohimin | Al-Quran dan Psikoterapi Elaborasi Deduktif

Sedangkan sebagai terapan psikoterapi mengupayakan pendekatan spritual dalam pencegahan dan pengobatan penyakit-penyakit yang berkaitan dengan mental dan kejiwaan yang bersarang dalam dada (al-qalb).

Orang yang tidak memiliki sifat pemaaf dan tidak memposisikan dirinya juga menjadi pemaaf atau meminta maaf termasuk orang yang fasiq yang dihinggapi virus penyakit zaikhun yang disebabkan karena ulahnya sendiri berpaling dari kebenaran. Nabi Musa as. Pernah direpotkan oleh virus yang berbahaya bagi keimanan seseorang. Allah swt. Maha bisa untuk membiarkan hambanya yang terkena virus ini. Virus zaighun adalah kecenderungan pada kesesatan dan bisa mengantarkan seseorang kepada kesesatan (dhalal), virus ini sebagai benih-benih kesesatan. Umat Nabi Musa as. Yang pernah terkena virus ini terus menyakiti dirinya, padahal Musa diutus kepada mereka sebagai utusan Allah. Virus ini ada kaitannya dengan ke-fasiqkan seseorang, Orang yang fasiq dan senantiasa bersifat fasiq bisa menjadi orang yang terkena virus ini dan membuatnya sesat. Allah mengingatkan dan memberi warmning "tidak memberi petunjuk kepada kaum yang fasik". Karena mereka berpaling dari kebenaran, Maka Allah membiarkan mereka sesat dan bertambah jauh dari kebenaran. Tatkala seseorang berpaling (dari kebenaran), maka Allah akan memalingkan hati

${ }^{21}$ Deduksi dan perintah Kitab Suci (al-Quran), “Jadilah sebagai orang pemaaf dan suruhlah orang berbuat makruf, serta jangan pedulikan orangorang yang bodoh". (al A'raf/7: 199).

${ }^{22}$ Lihat Q.S. at- Taghabun/64: 14

${ }^{23}$ Lihat Q.S. al-Baqarah/2: 263.

${ }^{24}$ Lihat Q.S. Ali ‘Imran/4: 159.

${ }^{25}$ Tasawuf Sebagai Terapi menawarkan cara Islami dalam pengobatan gangguan kejiwaan yang dialami manusia, yaitu dengan cara melalui terapi sufi. Terapi tasawuf bukanlah bermaksud mengubah posisi maupun menggantikan tempat yang selama ini di dominasi oleh medis, justru cara terapi sufi ini memiliki karakter dan fungsi melengkapi. Karena terapi tasawuf merupakan terapi pengobatan yang bersifat alternatif. Tradisi terapi di dunia sufi sangatlah khas dan unik. Ia telah dipraktekkan selama berabad-abad lamanya, namun anehnya baru di zaman-zaman sekarang ini menarik perhatian luas baik di kalangan medis pada umumnya, maupun kalangan terapis umum pada khususnya. Karena menurut Omar Alisyah, terapi sufi adalah cara yang tidak bisa diremehkan begitu saja dalam dunia terapi dan penanganan penyakit (gangguan jiwa), ia adalah sebuah alternatif yang sangat penting. (Omar Alishah, Tasawuf sebagai Terapi, Pustaka Hidayah, Bandung, 2002, h. 5) seseorang. Oleh karena itu, maka berhati-hatilah dengan virus zaighun ini, janganlah sampai seseorang berpaling dari kebenaran. Karena kebenaran akan memberi imunisasi dan dapat menagkal virus yang berbahaya ini. Virus zaighun ini biasanya bersarang di dalam hati dan menjadi musuh bebuyutan. ${ }^{26}$

\section{Kesimpulan}

Secara deduktif al-Quran menyatakan dirinya dan memberi tahu kepada manusia bahwa alQuran hadir sebagai penyembuh, terutama terhadap penyakit-penyakit yang berada di dalam dada atau penyakit mental. Karena al-Quran hadir sebagai pembelajaran, penyembuh, petunjuk, dan rahmat. Selain memiliki efek menenangkan dan menggetarkan jiwa, al-Qur'an juga memiliki efek preventif, kuratif, dan terapeutik terhadap berbagai penyakit kejiwaan, penyakit spiritual hingga penyakit fisik. Dalam konteks psikologi Islam, dalam diri manusia, penyakit bisa berasal dari tiga faktor yakni, sakit fisik dari pencernaan, sakit psikis, dan sakit karena gangguan Jin, Sihir dan 'Ain. Psikoterafi memaaf dan meminta maaf merupakan bagian dari psikoterapi tasauf, sebuah upaya psikoterapi yang menggabungkan pendekatan tasawuf dan psikoterapi. Menjadi pemaaf dan pemberi maaf serta berlapang dada ketika diminta maaf serta berusaha utuk meminta maaf sekaligus memberi terapi pada diri sendiri agar tidak menjadi beban psikologis terhadap diri sendiri dan orang lain. Karena bisa saja kekesalan pada diri sendiri akan menjadi penyakit mental dan juga bisa berdampak pada penyakit fisik (pisikosomatis).

\section{Daftar Pustaka}

Adz-Dzaky, M. Hamdani Bakran, Konseling dan Psikoterapi Islam, Fajar Pustaka, Yogyakarta, 2002.

\footnotetext{
${ }^{26}$ Lihat Q.S. Ali Imran/3 : 7-9 dan Q.S. ash-Shaf/61 : 5 .
} 
12

NUANSA Vol. XII, No. 1, Juni 2019

Alishah, Omar, Tasawuf sebagai Terapi, Pustaka Hidayah, Bandung, 2002.

Alishah, Terapi Sufi, Yogyakarta: Pustaka Sufi, 2004

Al-Taftazani, Abu Al Wafa Al-Ghanimi, Sufi dari Zaman Ke Zaman, Pustaka, Bandung, 1997.

Annajar, Amin, Psikoterapi Sufistik dalam Kehidupan Modern, Mizan Media Utama, Bandung, 2004.

Asmaran as, Pengantar Studi Tasawuf, PT. Raja Grafindo, Jakarta, 1992.

Aziz, Abdul, Psikologi Agama, Sinar Baru Algensindo, Bandung, 1987.

Bagir, Haidar, Manusia Modern Mendamba Allah, Penerbit Pustaka Amani Jakarta, 2002

Baharuddin, Paradigma Psikologi Islami, Studi tentang elemen Psikologi Dari Al-Quran, Pustaka Pelajar, Yogyakarta, 2007

Burhani, Ahmad Najib, Manusia Modern Mendamba Allah, Renungan Tasawuf Positif, Hikmah, Jakarta, 2002.

Darajat, Zakiah, Ilmu Jiwa Agama, Bulan Bintang, Jakarta, 2005

Kesehatan Mental, PT. Gunung Agung, Jakarta, 1982.

Faqih, Aunur Rahim, Bimbingan Konseling dalam Islam, UII Press, Yogyakarta, 2001.

Fahmi, Musthofa, Kesehatan Jiwa dalam Keluarga, Sekolah dan Masyarakat, Bulan Bintang, Jakarta, 1977

Hanna Djumhana Bastaman, Integrasi Psikologi Dengan Islam, Menuju Psikologi Islami, Yayasan Insan Kamil bekerjasama dengan Pustaka Pelajar, Yogyakarta, 2005

Hawari, Dadang, Ilmu Kedokteran Jiwa dan Kesehatan Jiwa, Dana Bakti Prima Jasa, Yogyakarta, 1999.
Iin Tri Rahayu, Psikoterapi Perspektif Islam \& psikologi Kontemporer, UIN Malang Press, Malang, 2009

Isep Zainal Arifin, Bimbingan Penyuluhan Islam, Pengembangan Dakwah Melalui Psikoterapi Islam, Rajawali Pers, Jakarta, 2009.

M. Solihin, Terafi Sufistik Penyembuhan Penyakit Kejiwaan Perspektif Tasauf, Pustaka Setia, Bandung, 2004.

Moh. Sholeh Imam Musbikin, Agama Sebagai Terapi, Telaah menuju Ilmu Kedokteran Holistik, Pustaka Pelajar, Yogyakarta, 2005.

Murtadlo, Ali, Bimbingan dan Konseling Islam Perspektif Sejarah, Jurnal Ilmu Dakwah, 2002.

Prayitno dan Erman Amti, Dasar-dasar Bimbingan Konseling, Rineka Cipta, Jakarta. 1999.

Rahman, Budy Munawar, Demam Tasawuf, Yogyakarta, 2000

Rahmat, Jalaluddin, Renungan Sufistik, Mizan, Bandung, 1997. , Psikologi Agama, Raja Grafindo Persada, Jakarta, 2000.

Rifa'i, Moh., Al-Qur'an dan Terjemahnya, Wicaksana, Jakarta, 1992.

Schimmel, Anne Marie, Terj. Supardi Joko Damono, dkk., Dimensi Mistik dalam Islam, Pustaka Firdaus, Jakarta, 1986.

Soleh, Moh, Agama Sebagai Terapi, Pustaka Pelajar, Yogyakarta, 2005

Suyuti, Ahmad, Percik-Percik Kesufian, Penerbit Pustaka Hidayah, Bandung 2002

Syukur, M. Amin, Tasawuf Kontekstual Solusi Problem Manusia Modern, Pustaka, Yogyakarta, 2003.

, Tasawuf dan Krisis, Pustaka Pelajar, Yogyakarta, 2001.

Zuhud di Abad Modern, Pustaka Pelajar, Jakarta, 1997. 